\title{
IDENTIFYING AREAS AFFECTED BY FIRES IN SUMATRA BASED ON TIME SERIES OF REMOTELY SENSED FIRE HOTSPOTS AND SPATIAL MODELING
}

\author{
Yudi Setiawan ${ }^{\mathrm{a}, \mathrm{c}}$, Lilik Budi Prasetyo ${ }^{\mathrm{a}, \mathrm{d}}$, Hidayat Pawitan ${ }^{\mathrm{b}}$, Prita Ayu Permatasaric, Desi Suyamto ${ }^{\mathrm{d}}$, Arif \\ Kurnia Wijayanto ${ }^{c}$ \\ a Departemen Konservasi Sumberdaya Hutan dan Ekowisata, Fakultas Kehutanan, Institut Pertanian Bogor, \\ Kampus IPB Darmaga, Bogor 16680 — setiawan.yudi@apps.ipb.ac.id \\ ${ }^{\mathrm{b}}$ Departemen Geofisika dan Meteorologi, Fakultas Matematika dan Ilmu Pengetahuan Alam, Institut Pertanian \\ Bogor, Kampus IPB Darmaga, Bogor 16680 \\ ${ }^{\mathrm{c}}$ Pusat Penelitian Lingkungan Hidup, Lembaga Penelitian dan Pengembangan kepada Masyarakat (PPLH- \\ LPPM), Institut Pertanian Bogor, Kampus IPB Darmaga, Bogor 16680 d \\ ${ }^{d}$ Forests 2020 Collaborative Program, Fakultas Kehutanan, Institut Pertanian Bogor, Kampus IPB Darmaga, \\ Bogor 16680
}

\begin{abstract}
Wildfires threaten the environment not only at local scales, but also at wider scales. Rapid monitoring system to detect active wildfires has been provided by satellite remote sensing technology, particularly through the advancement on thermal infrared sensors. However, satellite-based fire hotspots data, even at relatively high temporal resolution of less than one-day revisit period, such as time series of fire hotspots collected from TERRA and AQUA MODIS, do not tell exactly if they are fire ignitions or fire escapes, since other factors like wind, slope, and fuel biomass significantly drive the fire spread. Meanwhile, a number of biophysical fire simulation models have been developed, as tools to understand the roles of biophysical factors on the spread of wildfires. Those models explicitly incorporate effects of slope, wind direction, wind speed, and vegetative fuel on the spreading rate of surface fire from the ignition points across a fuel bed, based on either field or laboratory experiments. Nevertheless, none of those models have been implemented using real time fire data at relatively large extent areas. This study is aimed at incorporating spatially explicit time series data of weather (i.e. wind direction and wind speed), remotely sensed fuel biomass and remotely sensed fire hotspots, as well as incorporating more persistent biophysical factors (i.e. terrain), into an agent-based fire spread model, in order to identify fire ignitions within time series of remotely sensed fire hotspots.
\end{abstract}

Keywords: Forest fire, active fire, peatland, agent-based model

(Diterima: 24-02-2018; Disetujui: 30-03-2018)

\section{Introduction}

\subsection{Background}

Recently, the awareness of the wetland ecosystem change in tropical regions has increased considerably, especially in highly sensitive/vulnerable areas such as peat swamp area. Improving the understanding of forest landscapes through its interaction with climate, ecosystem processes, and biodiversity is an essential research challenge to the deforestation and forest degradation issue (Page et al., 2010; Achard et al, 2002), including the restoration of degraded peatland by forest fire. The Bonn Challenge is a global effort to restore 150 million hectares of the world's degraded and deforested lands by 2020 (IUCN, 2014).

Therefore, Indonesia is keen to collaborate with the Bonn Challenge because the program is in line with government's program in terms of conservation, rehabilitation and ecosystem restoration in degraded forests or primary forests and peatlands.

Wildfires threaten the environment not only at local scales, but also at wider scales. Wildfires from forests and peatlands over Southeast Asia during September to October 2015 were estimated to release $\mathrm{CO} 2$ at emission rate of about $11.3 \mathrm{Tg} \mathrm{CO} 2$ per day, exceeded $\mathrm{CO} 2$ emitted from fossil fuel combustion in European Union (EU28) of about 8.9 Tg CO2 per day (Huijnen, et al., 2016).

Peatlands are complex systems that reflect their geographical and ecological setting. Their characteristics and its changes are the results of interactions between socio-economic and cultural conditions, biophysical constraints and land use history (Cole et al., 2015). Development and stability of peatlands are determined as interactions between different land use/cover types, hydrological setting and spatial elements of the landscape (Evans and Moran, 2002).

The importance of tropical peatlands (tropical peat swamp lands) on the global carbon cycle and ecosystems has been studied by many researchers, such as changes in its ecological function (Archard, 2002) and declining in biodiversity through land conversion (Myers et al., 2000). Moreover, wildfires from forests and peatlands over Southeast Asia during September to October 2015 were estimated to release CO2 at emission rate of about $11.3 \mathrm{Tg} \mathrm{CO} 2$ per day, ex-ceeded $\mathrm{CO} 2$ emitted from fossil fuel combustion in European 
Union (EU28) of about 8.9 Tg CO2 per day (Huijnen, et al., 2016).

Rapid monitoring system to detect active wildfires has been provided by satellite remote sensing technology, particularly through the advancement on thermal infrared sensors (Giglio, et al., 2016; Kuenzer, et al., 2016; Panda, et al, 2016; Schroeder, et al., 2016). However, satellite-based fire hostspots data, even at relatively high temporal resolution of less than one-day revisit period, such as time series of fire hotspots collected from TERRA and AQUA MODIS (Kuenzer, et al., 2016), do not tell exactly if they are fire ignitions or fire escapes, since other factors like wind, slope, and fuel biomass significantly drive the fire spread (Balbi, et al., 2007; Balbi, et al., 2010; Mandel, et al., 2014; Monedero, et al., 2017; Morandini, et al., 2014). Thus, law enforcement efforts in order to mitigate severe environmental impacts due to wildfires through punishment mechanism to the combustion actors (e.g. Fajri, 2016), often hard to provide convincing evidence based on time series of remotely sensed fire hotspots per se, whether fire hotspots detected within the responsible area of suspects are truly ignited by the suspects or in fact escaped from the neighboring areas.

Meanwhile, a number of biophysical fire simulation models have been developed, as tools to understand the roles of biophysical factors on the spread of surface wildfires (Balbi, et al., 2007; Balbi, et al., 2010; Mandel, et al., 2014; Morandini, et al., 2014). Those models explicitly incorporate effects of slope, wind direction, wind speed, and vegetative fuel on the spreading rate of surface fire from the ignition points across a fuel bed, based on either field or laboratory experiments. Most recently, Monedero, et al. (2017) develop a conceptual model to trace back fire ignition points of a given perimeter of final fire. Nevertheless, none of those fire models have been implemented using real time fire data at relatively large extent areas.

Moreover, with regards to wildfires on peatlands, which spread is not only determined by aboveground biomass fuel on the surface, but also determined by belowground biomass fuel on the sub-surface within peat layers, Condro (2017) developed a threedimensionally explicit model of peatland hydrology, capturing wetness or dryness of peat layers due to hydro-dynamics processes in daily time-step, thus, applicable to explore fire spread within the sub-surface.

Regardless of the debate on the different methodology of forest fire control resulted in under estimation figure, the decrease of forest cover in Sumatran peat swamp is obvious and needs immediate response. Spatial modeling of fire spread and fire ignition will assist the policy makers to understand the process and to consider it when decisions are made. The fire spread modelling in Sumatra by using spatial modelling tool can be used as data input to solve environmental problem resulted from forest fire, such as smoke disaster.

\subsection{Objective}

Due to incorporating spatially explicit time series data of weather, remotely sensed fuel biomass and remotely sensed fire hotspots, as well as incorporating more persistent biophysical factors (e.g. terrain and physical peat properties), into an agent-based fire spread model, the objectives of research are 1) to develop fire spread model; and 2) to identify fire ignitions within time series of remotely sensed fire hotspots using the model, in order to develop simple criteria and indicators of fire risk for decision makers.

\section{Methodology}

\subsection{Study site}

This research will be conducted in a forest concession (permit for carbon sequestration concession) in South Sumatra. The area is managed by Global Alam Lestari - PT. GAL, which has ex-perienced widespread fire events in 2015 (Figure 3). Figure 1 shows the research site (PT. GAL) (right figure) and spatial distribution of fire hotspots in Sumatra throughout September 2015 (yellow) and October 2015 (red) detected using TERRA/AQUA MODIS imageries at confi-dence level of $\geq 80 \%$ (left figure). We selected this specific site as it has a wide range of fire se-verity levels in South Sumatra.

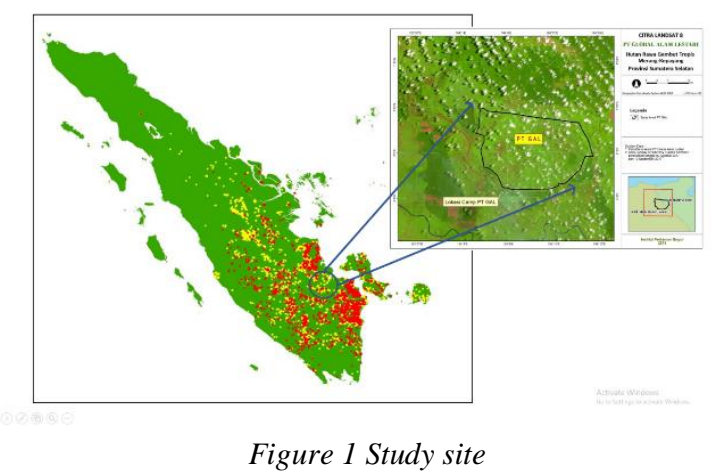

\subsection{Data}

There are two data types used for parameterizing the model: spatial and tabular. Tabular data consist of: (i) meteorological parameters, (ii) peat parameters, and (iii) land cover parameters. Spatial data consist of: (i) land cover map, classified from Landsat 8 imagery of path/row 125/61 with acquisition date of September 10th 2017, (ii) digital elevation model (DEM) based on SRTM, and (ii) peat thickness map, based on surface interpolation of ground measurement points. In this case, the spatial data were resampled into 30-m. Data used in this study detail is provided in Table 1. 
Table 1. Data used in this study

\begin{tabular}{|c|c|c|c|c|c|}
\hline No. & Category & Data & $\begin{array}{l}\text { Temporal } \\
\text { resolution }\end{array}$ & Spatial resolution & Source \\
\hline 1 & Fire properties & Fire hotspots & $<1$ day & $1 \mathrm{~km}$ & $\begin{array}{l}\text { TERRA/AQUA MODIS Fire } \\
\text { Products }\end{array}$ \\
\hline 2 & Surface properties & DEM & - & $30 \mathrm{~m}$ & SRTM or Aster \\
\hline 3 & Surface properties & Biomass fuel & 16 days & $0.2 \mathrm{~km}$ & MODIS EVI \\
\hline 4 & Surface properties & River & - & Scale 1:50,000 & $\begin{array}{l}\text { Indonesian Geospatial } \\
\text { Information Agency }\end{array}$ \\
\hline 5 & Surface properties & $\begin{array}{l}\text { Land cover } \\
\text { maps }\end{array}$ & 1 year & $30 \mathrm{~m}-1 \mathrm{~km}$ & Landsat 8 or MODIS \\
\hline 6 & Weather/climate properties & $\begin{array}{l}\text { Wind direction } \\
\text { and wind speed }\end{array}$ & 6 hours & $0.125^{\circ}$ & $\begin{array}{l}\text { European Centre for Medium- } \\
\text { Range Weather Forecasts } \\
\text { https://www.ecmwf.int/ } \\
\text { Climate Hazards Group }\end{array}$ \\
\hline 7 & Weather/climate properties & Rainfall & 1 day & $5.5 \mathrm{~km}$ & $\begin{array}{c}\text { InfraRed Precipitation with } \\
\text { Stations (CHIRPS) } \\
\text { http://iridl.ldeo.columbia.edu/ }\end{array}$ \\
\hline 8 & Weather/climate properties & $\begin{array}{c}\text { Potential } \\
\text { evapotranspirati } \\
\text { on }\end{array}$ & 1 day & $(0.925 \mathrm{~km})$ & $\begin{array}{l}\text { Available weather stations or } \\
\text { remotely sensed estimation (e.g. } \\
\text { WorldClim } \\
\text { http://worldclim.org/version2) }\end{array}$ \\
\hline
\end{tabular}

\subsection{Data Analysis}

Most of available land cover maps are determined by applying single-date satellite imagery, which was necessarily coincident with temporarily cover types, such as barren land. IN this work, we will explore 250 m multi-temporal MODIS EVI 16-day composite data year 2015-2016 to characterize the vegetation dynamics of the peatlands in Java. Although an issue about the availability of sufficient quality of data sets had been arising out of the time-series analysis of MODIS, but we will use the filtered dataset by wavelet function in order to identify and reduce the overall noise so as not to lose useful information from the time series data (Setiawan, et al. 2011).
In general, the activities will develop a 2D fire model that simulates fire spread on surface only, and a 3D fire model that simulates fire spread either on surface or sub-surface. The models will be developed using agent-based modelling tool - NetLogo (Wilensky, 1999). Temporal resolution of the model is 6 hours, with 2D spatial resolution $1 \mathrm{~km}^{2}$ and $3 \mathrm{D}$ spastial resolution $1 \mathrm{~km} 2 \times 0.1 \mathrm{~m}$. Actual fire hotspots at time $\mathrm{t}$ will be simulated using the model for $\Delta \mathrm{t}$ time period. Simulated fires at time $\mathrm{t}+\Delta \mathrm{t}$ will be compared with actual fire hotspots at time $\mathrm{t}+\Delta \mathrm{t}$. If actual fire hotspots are nearby the paths of simulated fires, then it is most likely that the actual fire hotspots are fire escapes. Otherwise, actual fire hotspots are most likely new fire ignitions.

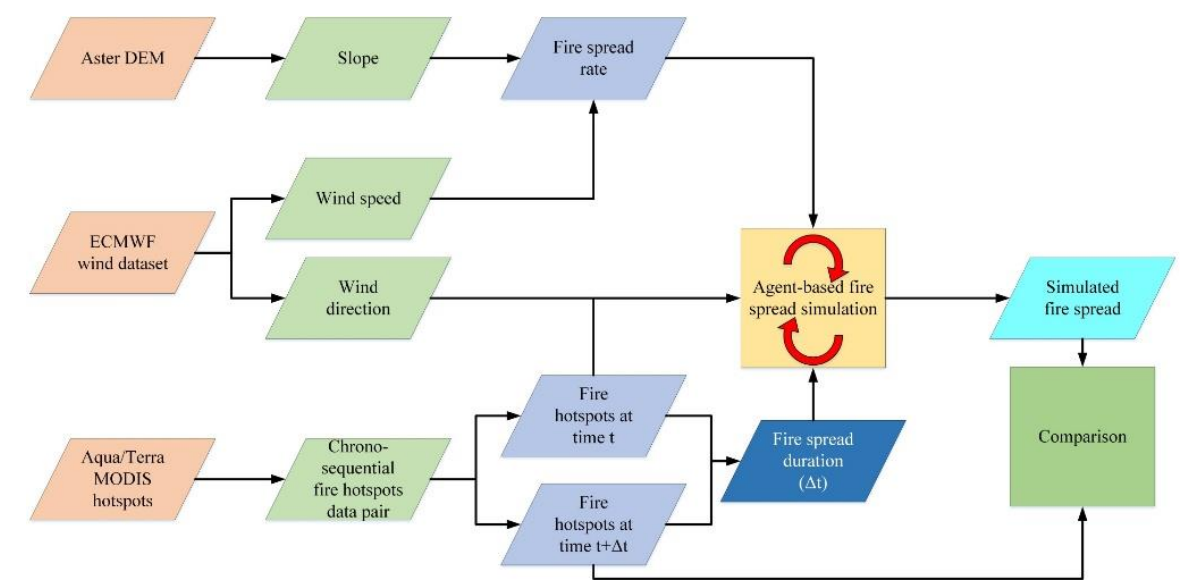

Figure 2. Flowchart data analysis

\section{Results and Discussion}

\subsection{Development of Surface Fire Model}

In general, the activities will develop a 2D fire model that simulates fire spread on surface only, and a 3D fire model that simulates fire spread either on surface or sub-surface. The models will be developed using agent-based modelling tool - NetLogo (Wilensky, 1999). Temporal resolution of the model is 6 hours, with $2 \mathrm{D}$ spatial resolution $1 \mathrm{~km} 2$ and $3 \mathrm{D}$ spastial resolution $1 \mathrm{~km} 2 \times 0.1 \mathrm{~m}$. Actual fire hotspots at time $\mathrm{t}$ will be simulated using the model for $\Delta \mathrm{t}$ time period. Simulated fires at time $\mathrm{t}+\Delta \mathrm{t}$ will be compared with actual fire hotspots at time $\mathrm{t}+\Delta \mathrm{t}$. If actual fire hotspots are nearby the paths of simulated fires, then it is most 
likely that the actual fire hotspots are fire escapes. Otherwise, actual fire hotspots are most likely new fire ignitions. Currently, the model of surface fire was developed based on fire spread velocity using the equation adopted from Morandini, et al. (2014) and Mandel, et al. (2014) as follows:

$$
((0.0002 * \text { slope })+0.0089)+\text { wind speed }
$$

To evaluate the model behavior, the preliminary results of the model can be seen in Figure 3, Figure 4, and Figure 5.

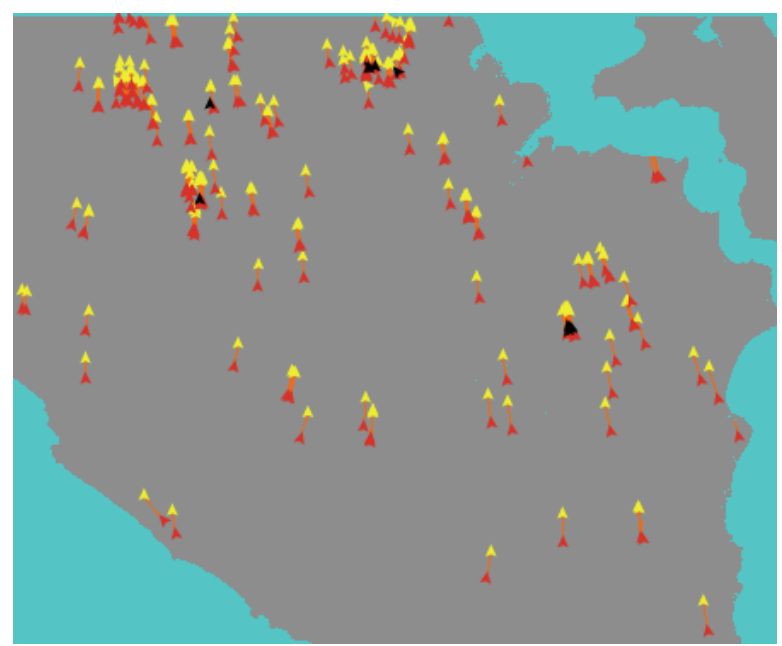

Figure 3. Fire events with duration from 02-Sep-2015, 06:00:00 to 12:00:00 (6 hours).

Red triangles indicate MODIS fire hotspots on 02Sep-2015 at 06:00:00, black triangles indicate MODIS fire hotspots on 02-Sep-2015 at 12:00:00, yellow triangles indicate simulated fire spread, and orange lines indicate path of simulated fire spread. In this case, all fire hotspots on 02-Sep-2015 at 12:00:00 (black triangles) were probably fire escapes - spread through wind- since the positions were on the path of simulated fire spread.

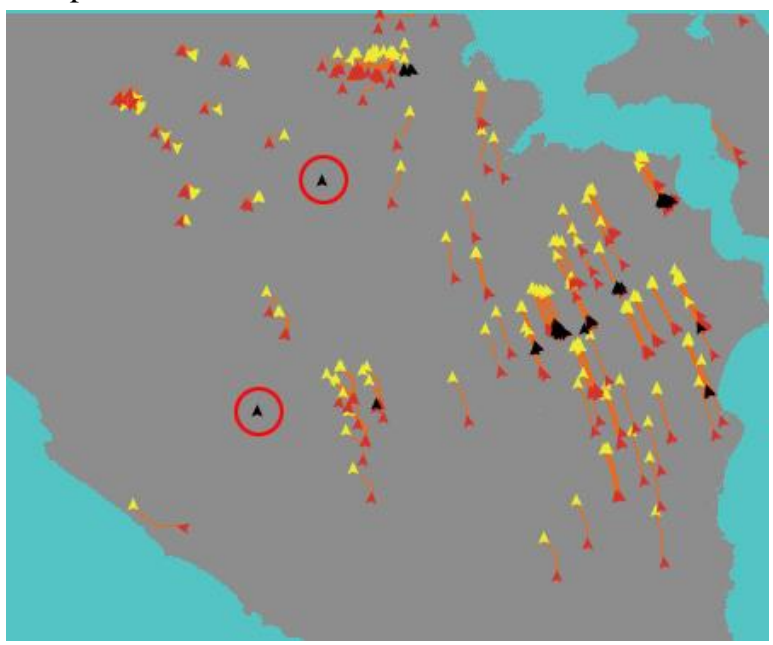

Figure 4. Fire events with duration from 09-Sep-2015, 06:00:00 to 10-Sep-2015, and 00:00:00 (18 hours)
Red triangles indicate MODIS fire hotspots on 09Sep-2015 at 06:00:00; black triangle indicate MODIS fire hotspots on 10-Sep-2015 at 00:00:00, yellow triangles indicate simulated fire spread, and orange lines indicate path of simulated fire spread. In this case, few fire hotspots on 10-Sep-2015 at 00:00:00 (black triangles within red circle) were probably fire ignitions, otherwise most of them were probably fire escapes spread through wind.

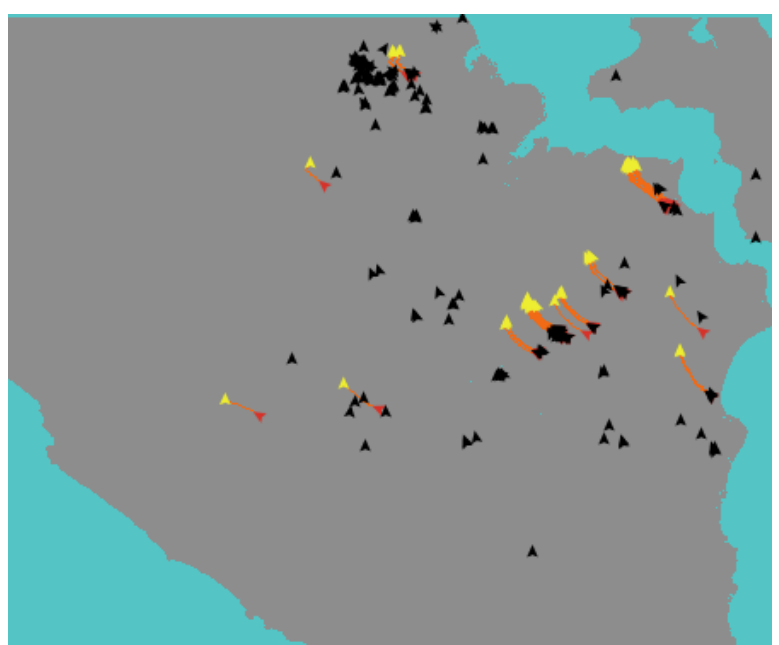

Figure 5. Fire events with duration from 10-Sep-2015, 00:00:00 to 12:00:00 (12 hours)

Red triangles indicate MODIS fire hotspots on 10Sep-2015 at 00:00:00, black triangles indicate MODIS fire hotspots on 10-Sep-2015 at 12:00:00, yellow triangles indicate simulated fire spread, and orange lines indicate path of simulated fire spread. In this case, most of fire hotspots on 10-Sep-2015 at 12:00:00 were probably fire ignitions, otherwise few of them (close to orange lines) were probably fire escapes - spread through wind.

Some of biophysical fire simulation models have been developed in three provinces in Sumatra Island (Riau, Jambi, and South Sumatra) during July-October 2015 as tools to understand the roles of biophysical factors on the spread of surface wildfires. Those models explicitly incorporate effects wind direction and wind speed. Optimized hotspot analysis with confidence level over $90 \%$ in collaboration with the wind direction and speed in Riau, Jambi, and South Sumatra during July - October 2015 can be seen in Figure 7, Figure 8, and Figure 9 respectively. 


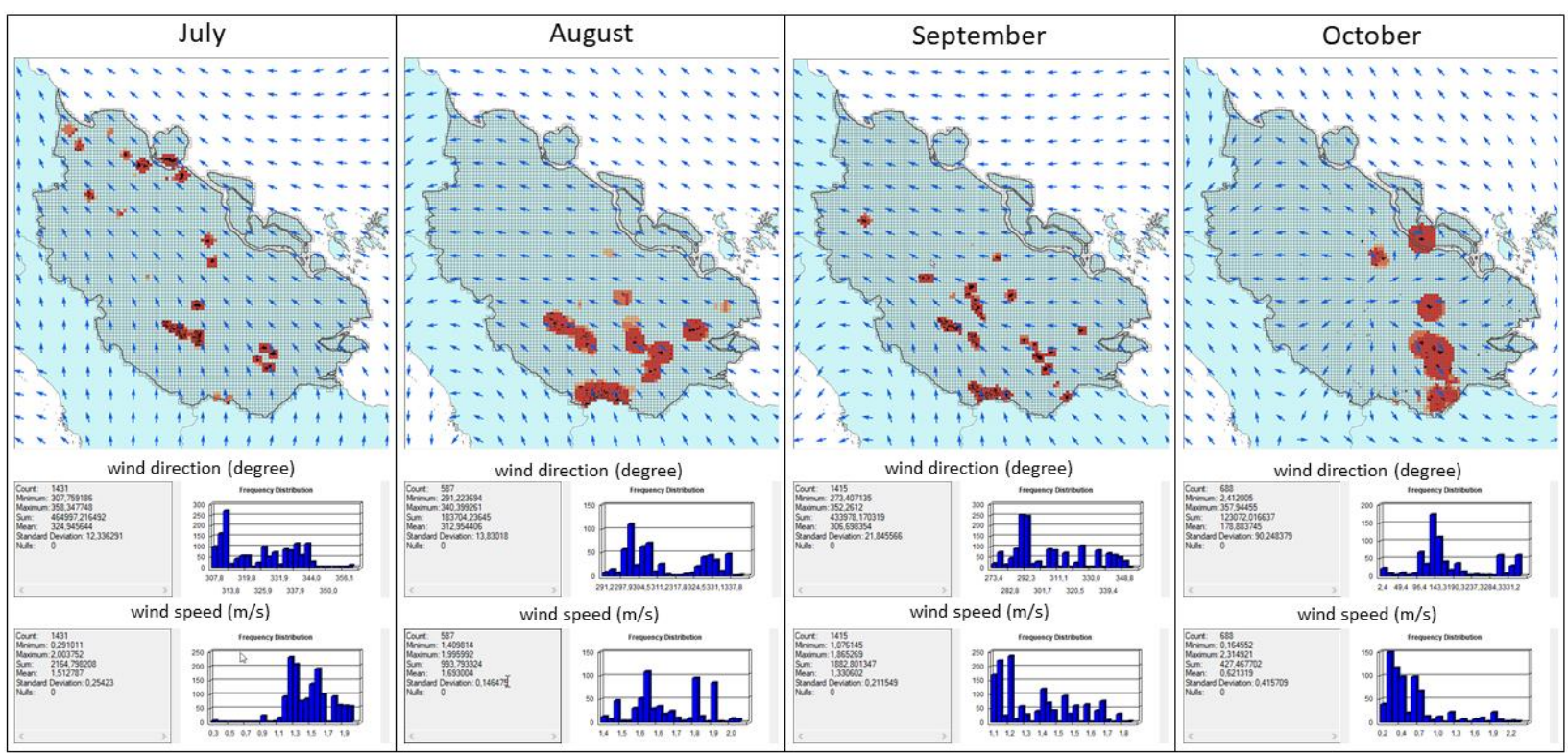

Figure 6. Optimized hotspot analysis with confidence level over $90 \%$ in collaboration with the wind direction and speed in Riau during July - October 2015

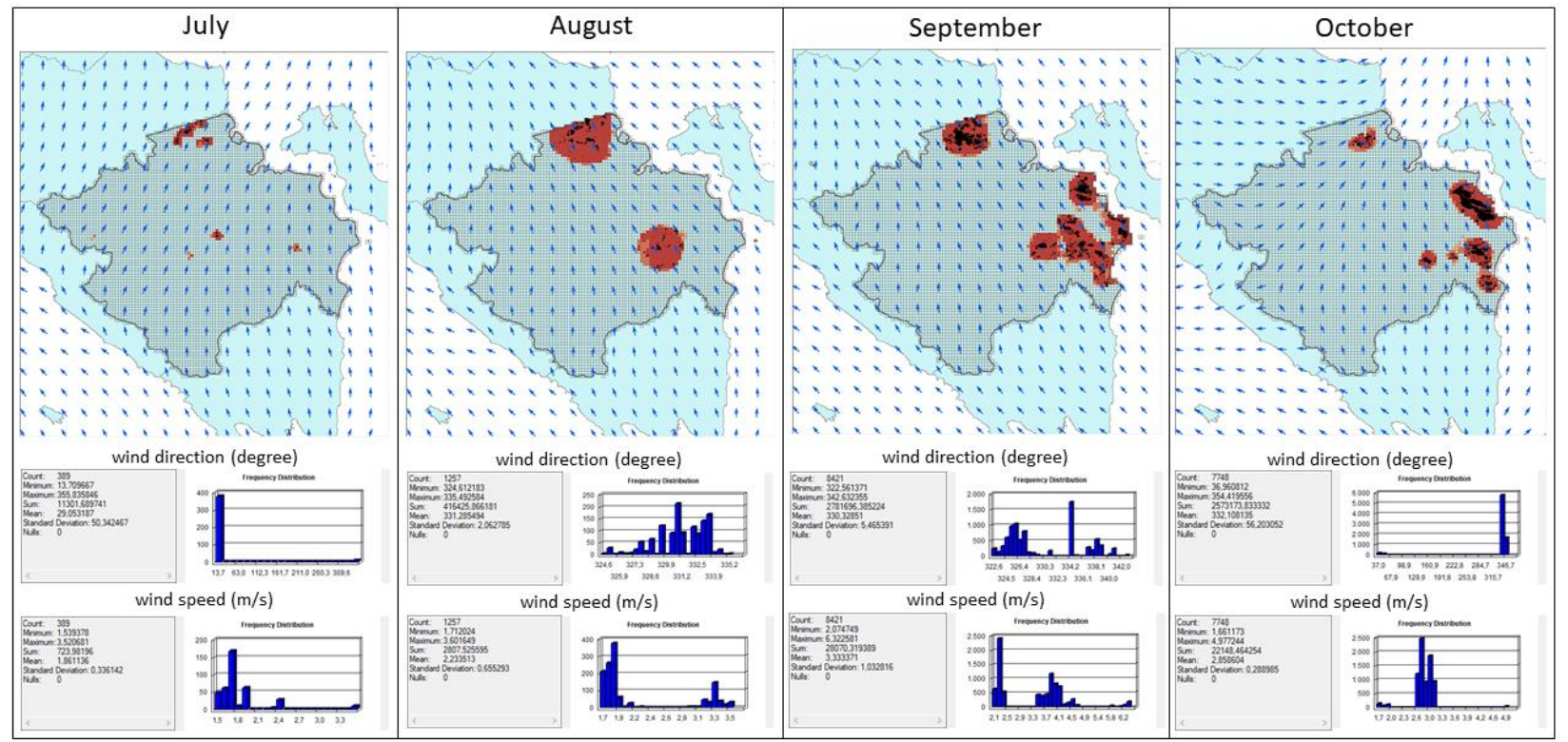

Figure 7. Optimized hotspot analysis with confidence level over $90 \%$ in collaboration with the wind direction and speed in South Sumatra during July - October 2015

\subsection{Survey Location: PT Global Alam Lestari (PT $G A L)$}

PT GAL is a forest concession rights established in 2013 and located in the tropical peat swamp forest of Merang-Kepayang, South Sumatra, Indonesia. PT GAL is located in Bayung Lencir Subdistrict, Musi Banyuasin Regency, South Sumatra Province and the entire area stands on 22,280 hectares of peatland. Peat depth in PT GAL ranges from 1-8 meters (average 4 meters).
PT GAL was established for several strategic targets, including:

1. Improving the quality of peat swamp forest

2. Maintenance and / or increase in carbon stock volume in peat swamp forest areas

3. Reducing the level of deforestation and forest degradation

4. Increased participation and empowerment of communities around the forest

5. Research and development 
6. Infrastructure Development and Management of Peat Water

7. Selected Flora Habitat Restoration

8. Inventory of Forest Stand and Carbon Reserves

9. Collection of Survey Data

But its main purpose is to optimize the utilization and manage the production forests through organizing forest carbon in order to manage sustainable forest and mitigate the climate change.

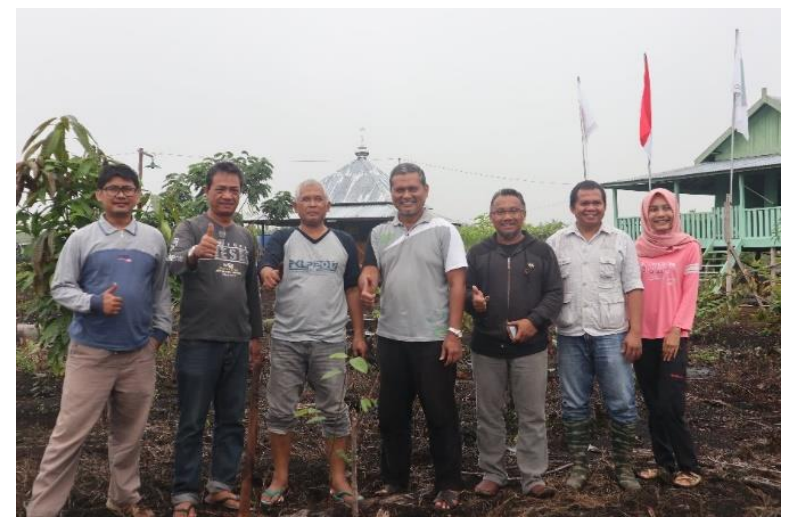

Figure 8. Survey activity in PT GAL April 2018

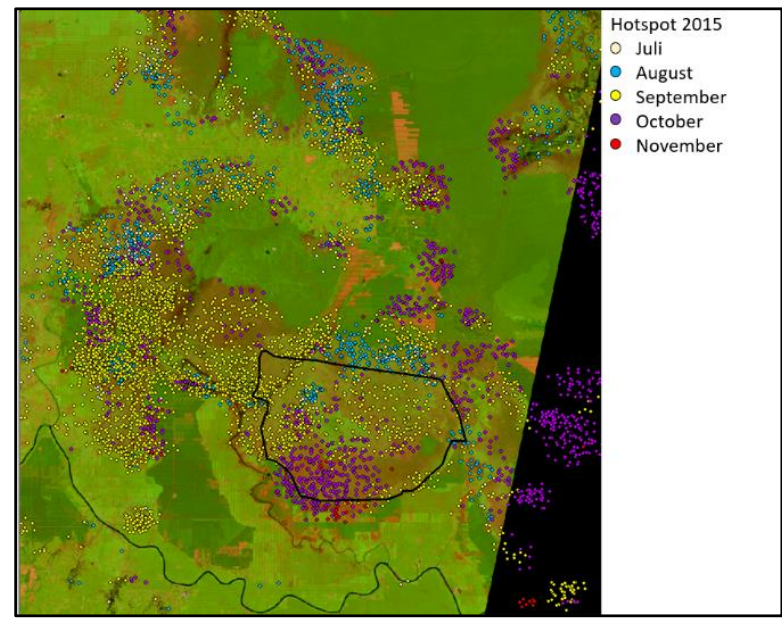

Figure 9. Monthly hotspot fire event on 2015 based on visual interpretation over study area

At the location, there are several infrastructure facilities to support various activities such as camps, guard posts, boats, motorized vehicles, and firefighters. PT GAL routinely carries out various activities to prevent the illegal logging, nurseries, environmental services such as extinction and prevent forest and land fires, research, peat hydrology surveillance, forest development, water management with drones, channel blocking, planting, carbon accounting, and local community empowerment.

\subsection{Multispectral UAV Based Analysis}

Aerial data has been collected by using Unmanned Aerial Vehicle (UAV) or drone over the study area. The drone was equipped with a multispectral camera (green, red, red edge, and near infrared or NIR). The objective of collecting this aerial data was to relate the event of fire that happened on 2015 to the characteristic of vegetation covering the burned area. This data will be valuable for further model development in the next stage.

There are two Area of Interest (AOI) for aerial data collection. The areas were selected based on 2015 fire event.

1. AOI 1: Area which were not burned on 2015 fire event.

2. AOI 2: Area which were burned on 2015 fire event.

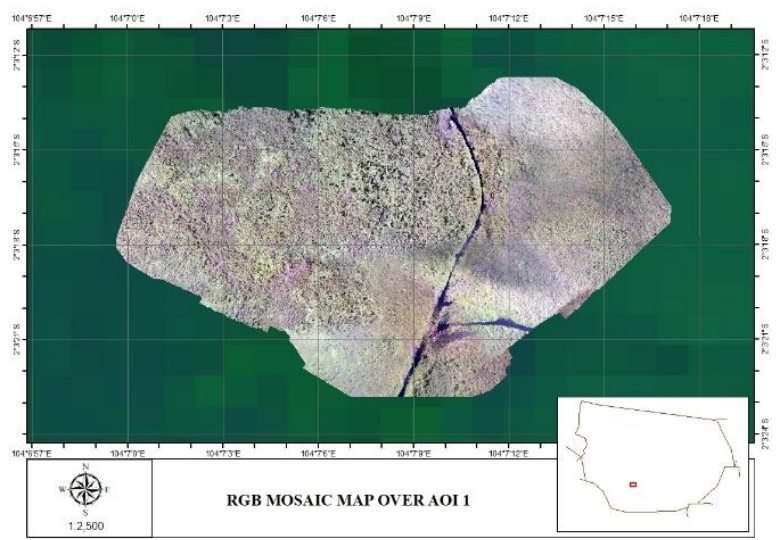

Figure 10. True color composite (RGB) over AOI 1

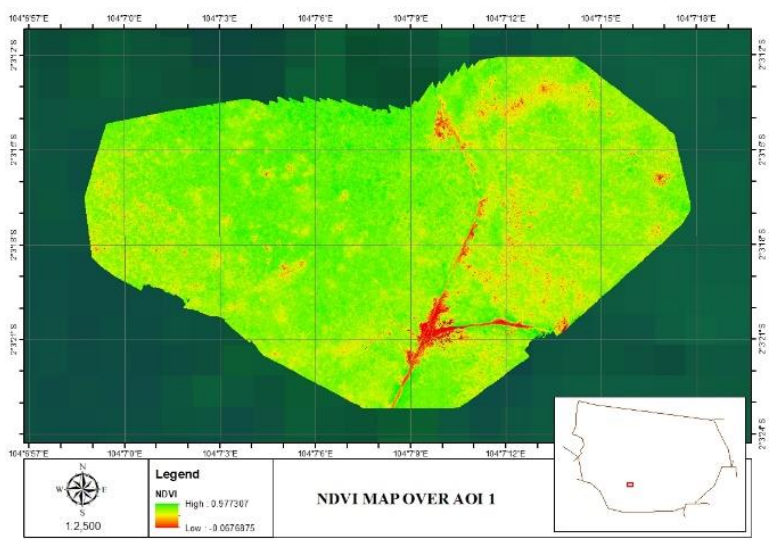

Figure 11. NDVI map over AOI 1. The value ranged from 0.0677 to 0.9773

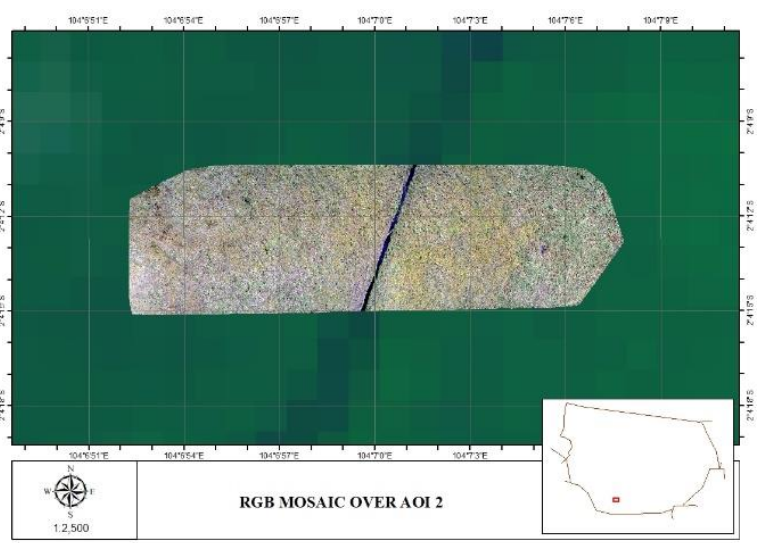

Figure 12. True color composite (RGB) over AOI 2 


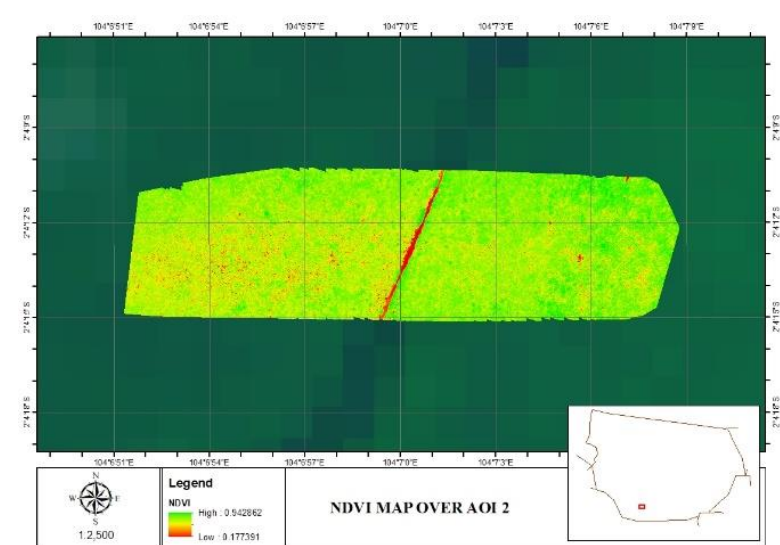

Figure 13. NDVI map over AOI 2. The value ranged from 0.1774 to 0.9428

\section{Conclusions}

Wildfires threaten the environment not only at local scales, but also at wider scales. Rapid monitoring system to detect active wildfires has been provided by satellite remote sensing technology, particularly through the advancement on thermal infrared sensors. However, satellite-based fire hotspots data, even at relatively high temporal resolution of less than one-day revisit period, such as time series of fire hotspots collected from TERRA and AQUA MODIS, do not tell exactly if they are fire ignitions or fire escapes, since other factors like wind, slope, and fuel biomass significantly drive the fire spread.

Meanwhile, a number of biophysical fire simulation models have been developed, as tools to understand the roles of biophysical factors on the spread of wildfires. Those models explicitly incorporate effects of slope, wind direction, wind speed, and vegetative fuel on the spreading rate of surface fire from the ignition points across a fuel bed, based on either field or laboratory experiments. Nevertheless, none of those models have been implemented using real time fire data at relatively large extent areas. This study is aimed at incorporating spatially explicit time series data of weather (i.e. wind direction and wind speed), remotely sensed fuel biomass and remotely sensed fire hotspots, as well as incorporating more persistent biophysical factors (i.e. terrain), into an agent-based fire spread model, in order to identify fire ignitions within time series of remotely sensed fire hotspots

\section{Acknowledgements}

We would like to thank the Center for Environmental Research, Bogor Agricultural University (PPLHIPB) for giving us opportunity to get the research funding. This work was supported by Indonesian Directorate General of Higher Education (DIKTI) for fiscal year 2017 under the scheme of International Research Collaboration.

\section{References}

[1] Achard F, Eva HD, Stibig HJ, Mayaux P, Gallego J, Richards T, Malingreau JP. Determination of deforestation rates of the world's humid tropical forests. Science 2002; 297:999-1002.

[2] Balbi, J-H., Rossi, J-L., Marcelli, T., Chatelon, F-J., 2010. Physical modeling of surface fire under nonparallel wind and slope conditions. Combust. Sci. and Tech. 182, 922-939.

[3] Balbi, J-H., Rossi, J-L., Marcelli, T., Santoni, P-A., 2007. A 3D physical real-time model of surface fires across fuel beds. Combust. Sci. and Tech. 179, 2511-2537.

[4] Ballard CE, McIntyre N, Wheater HS, Holden J, Wallage ZE. 2011. Hydrological modelling of drained blanket peatland. Journal of Hydrology 407: 81-93.doi: 10.1016/j.jhydrol.2011.07.005

[5] Cole LES, Bhagwat SA and Willis KJ 2015 Long-term disturbance dynamics and resilience of tropical peat swamp forests. J. Ecol 103 16-30

[6] Condro, A.A. 2017. A 3D Voxel-based Model of Peatland Hydrology. Undergraduate thesis. Department of Geophysics and Meteorology, Faculty of Mathematics and Natural Sciences, Bogor Agricultural University, Bogor, Indonesia (In Press)

[7] Costanza R. 1989. Model goodness of fit: a multiple resolution procedure. Ecological Modeling 47: 199-215.Evans TP and Moran EF 2002 Spatial integration of social and biophysical factors related to landcover change. Popul Dev Rev 28 165-186

[8] Fajri, M.N., 2016. Penindakan pelaku pembakaran hutan dan lahan dengan pendekatan undang-undang pemberantasan tindak pidana korupsi. Integritas 2 (1), 43-68

[9] Giglio, L., Schroeder, W., Justice, C.O., 2016. The collection 6 MODIS active fire detection algorithm and fire products. Remote Sens. Environ. 178, 31-41.

[10] Hayasaka H, Takahashi H, Limin H, Yulianti N, Usup A. 2016. Peat fire occurence. Di dalam: Osaki M, Tsuji N, editor. Tropical Peatland Ecosystems. Tokyo (JP): Springer.

[11] Holden J, Kirkby MJ, Lane SN, Milledge DG, Brookes CJ, Holden V, McDonald AT. 2008. Overland flow velocity and roughness properties in peatlands. Water Resources Research 44(6): 1-11.doi:10.1029/2007WR006052

[12] Huijnen, V., Wooster, M. J., Kaiser, J. W., Gaveau, D. L. A. , Flemming, J., Parrington, M., Inness, A., Murdiyarso, D., Main, B., van Weele, M., 2016. Fire carbon emissions over maritime Southeast Asia in 2015 largest since 1997. Sci. Rep. 6 (26886).

[13] Kuenzer, C., Zhang, J., Dech, S., 2016. Thermal infrared remote sensing: principles and theoretical background. In: Thenkabail, P.S. (Ed.), Remote Sensing Handbook Volume I: Remotely Sensed Data Characterization, Classification, and Accuracies. CRC Press, Boca Raton, FL, USA.

[14] Mandel, J., Amram, S., Beezley, J. D., Kelman, G., Kochanski, A. K., Kondratenko1, V. Y., Lynn, B. H., Regev, B., Vejmelka, M., 2014. Recent advances and applications of WRF-SFIRE. Nat. Hazards Earth Syst. Sci.14, 2829-2845.

[15] Monedero, S., Ramirez, J., Molina-Terrén, D., Cardil, A., 2017. Simulating wildfires backwards in time from the final fire perimeter in point-functional fire models. Environ. Model. Softw. 92, 163-168.

[16] Morandini, F., Silvani, X., Honore', D., Boutin, G., Susset, A., Vernet, R., 2014. Slope effects on the fluid dynamics of a fire spreading across a fuel bed: PIV measurements and $\mathrm{OH}^{*}$ chemiluminescence imaging. Exp. Fluids 55 (1788), 1-12.

[17] Panda, S.S., Rao, M.N., Thenkabail, P.S., Fitzerald, J.E., 2016. Remote sensing systems - platforms and sensors: aerial, satellite, UAV, optical, radar, and LiDAR. In: Thenkabail, P.S. (Ed.), Remote Sensing Handbook Volume I: Remotely Sensed Data Characterization, Classification, and Accuracies. CRC Press, Boca Raton, FL, USA. 
[18] Page SE, Rieley JO, Banks CJ. Global and regional importance of the tropical peatland carbon pool. Global Change Biology 2010; 17:798818.

[19] Pianosi F, Beven K, Freer J, Hall JW, Rougier J, Stephenson DB, Wagener T. 2016. Sensitivity analysis of environmental models: a systematic review with practical workflow. Environmental Modelling \& Software 79: 214-232.

[20] Piao S, Gang JF, Ciais P, Peylin P, Huang Y, Sitch S, Wang T. The carbon balance of terrestrial ecosystems in China. Nature 2009; 458:1009-13.

[21] Prakash, A., Kuenzer, C., 2016. Remote sensing-based mapping and monitoring of coal fires. In: Thenkabail, P.S. (Ed.), Remote Sensing Handbook Volume III: Remote Sensing of Water Resources, Disasters, and Urban Studies. CRC Press, Boca Raton, FL, USA.

[22] Schroeder, W., Oliva, P., Giglio, L., Quayle, B., Lorenz, E., Morelli, F., 2016. Active fire detection using Landsat-8/OLI data. Remote Sens. Environ. 185, 210-220.

[23] Setiawan Y, Pawitan H, Prasetyo LB, Lubis MI, Parlindungan $\mathrm{M}$ and Nurdiana A 2016 Characterizing spatial distribution and environments of sumatran peat swamp area using $250 \mathrm{M}$ multitemporal MODIS data. Proc Env Sci 33 117-127

[24] Vadrevu, K.P., Lasko, K., 2016. Satellite-derived nitrogen dioxide variations from biomass burning in a subtropical evergreen forest, Northeast India. In: Thenkabail, P.S. (Ed.), Remote Sensing Handbook Volume III: Remote Sensing of Water Resources, Disasters, and Urban Studies. CRC Press, Boca Raton, FL, USA.

[25] Van Loon AF. 2015. Hydrological drought explained. WIREs Water 2015.doi: 10.1002/wat2.1085

[26] Van Noordwijk M, Farida A, Suyamto D, Lusiana B, Khasanah N. 2003. Spatial variability of rainfall governs river flow and reduces effects of land use change at landscape scale: GenRiver and SpatRain simulations. Di dalam: Post DA, editor. Modsim 2003: International Congress on Modelling and Simulation; 2003 Jul 14-17; Townsville, Australia. Townsville (AU): CSIRO.hlm 572-577.

[27] Wilensky, $\quad$ U., $1999 . \quad$ NetLogo (http://ccl.northwestern.edu/netlogo/). Center for Connected Learning and Computer-Based Modeling (CCL). Northwestern University, Evanston, IL, USA.

[28] Wilensky U dan Rand W. 2015. An Introduction to AgentBased Modeling. Massachusetts (US): The MIT Press.

[29] Xie Z, Di Z, Luo Z, Ma Q. 2012. A quasi-three-dimensional variably saturated groundwater flow model for climate modeling. Journal of Hydrometeorology 13(1): 27 46.doi:10.1175/jhm-d-10-05019.1. 